\title{
Imprensa feminina e sexualidade: 1946-1973
}

\author{
DOI: 10.15175/1984-2503-201810302
}

Anna Marina Barbará Pinheiro*

\section{Resumo}

Este artigo faz parte de pesquisa que teve como objeto de estudo as representações sobre o gênero feminino e a sexualidade das mulheres construídas pela Igreja, a Medicina e a Imprensa Feminina no Brasil entre 1946 e 1973. Este recorte cronológico inseriu-se na perspectiva de testarmos a hipótese de ter havido no país uma disjunção entre liberalização dos costumes e aumento do autoritarismo político. Assim, o período estudado compreendeu duas conjunturas diferenciadas: a que se estendeu de 1946 a 1964, e foi marcada pela resistência cultural combinada com mudanças de valores tradicionais no que tange aos costumes e a que se estendeu de 1964 a 1973, e é marcada pelo crescente autoritarismo político e por uma liberalização de costumes também crescente. No presente trabalho investigaremos empiricamente revistas femininas representativas de diferentes tendências de abordagem da temática da sexualidade, em cada uma das conjunturas estudadas. Com periodicidades diversas, aquelas que cobriam a conjuntura que vai do pós-guerra ao início dos anos 60 (Jornal das Moças e Capricho), se caracterizou por tratar de tal temática apenas de forma indireta, através da propaganda de medicamentos para as disfunções do aparelho reprodutivo feminino e de absorventes higiênicos. Do início dos anos 60 em diante analisamos a revista Claudia, que encontrou condições de abordar a questão da sexualidade, tanto em colunas regulares sobre "comportamento", quanto nas "seções de cartas"; divulgando as ideias feministas quanto ao tema.

Palavras-chave: Sexualidade; imprensa feminina; Jornal das Moças; revista Capricho; revista Cláudia.

\section{Prensa femenina y sexualidad: 1946-1973}

\section{Resumen}

Este artículo forma parte de la investigación cuyo objeto de estudio fueron las representaciones sobre el género femenino y la sexualidad de las mujeres construidas por la Iglesia, la medicina y la prensa femenina en el Brasil del año 1946 al 1973. Se trata de un recorte cronológico con vistas a poner a prueba la hipótesis de que en el país haya existido una disyunción entre liberalización de las costumbres y aumento del autoritarismo político. Así, en el período estudiado se distinguen dos coyunturas diferenciadas: la que se extendió de 1946 a 1964 y estuvo marcada por la resistencia cultural combinada con cambios en los valores tradicionales en lo que respecta a las costumbres y la que se prolongó de 1964 a 1973, marcada por el creciente autoritarismo político y por una liberalización de costumbres también en ascenso. En el presente trabajo investigaremos empíricamente revistas femeninas representativas de diferentes tendencias de tratamiento de la sexualidad en cada una de las coyunturas estudiadas. Con periodicidades diversas, aquellas que cubrían la coyuntura que va desde la posguerra al inicio de los años 60 (Jornal das Moças y Capricho), se caracterizaron por tratar tal temática de forma indirecta, a través de la propaganda de medicamentos para las disfunciones del aparato reproductor femenino y de absorbentes higiénicos. Desde el inicio de los años 60 en adelante, analizamos la revista Claudia, que encontró la forma de abordar la

\footnotetext{
* Professora do Departamento de Ciência Política do Instituto de Filosofia e Ciências Sociais da Universidade Federal do Rio de Janeiro - FCS/UFRJ e do Programa de Pós-Graduação em Políticas Públicas em Direitos Humanos do NEPP-DH/UFRJ. Doutora em História Social pela Universidade Federal Fluminense, mestre em História Social pela Universidade Federal Fluminense, bacharel em Sociologia e Política pela Pontifícia Universidade Católica do Rio de Janeiro, E-mail: annapin09@gmail.com. Orcid ID: https://orcid.org/0000-0002-3192-3663
} 
cuestión de la sexualidad, tanto en columnas regulares sobre "comportamiento", como en las "secciones de cartas», divulgando las ideas feministas sobre el tema.

Palabras clave: sexualidade; prensa feminina; Jornal das Moças; revista Capricho; revista Cláudia.

Women's press and sexuality: 1946-1973

\section{Abstract}

The following article forms part of research investigating representations of the female gender and women's sexuality as shaped by the Church, medicine and women's interest press in Brazil from 1946 to 1973. The defining of such a time period allowed us to gauge whether the country experienced a disjunction between a liberalization of customs and an increase in political authoritarianism. The period under study therefore encompasses two distinct historical moments, with 1946 to 1964 marked by cultural resistance combined with a shift in traditional values in terms of customs, and 1964 to 1973, marked by a growing political authoritarianism and a similar liberalization of customs. We conduct empirical research into women's interest magazines representative of different trends for approaching the subject of sexuality for each of the historical moments studied. In circulation across different time periods, those spanning the postwar period to the early 1960s (Jornal das Moças and Capricho) are characterized by their indirect treatment of the subject, advertising medicines for female reproductive disorders and feminine hygiene products. From the 1960s onwards, we turn our attention to Cláudia magazine, which came to approach the subject of sexuality both in regular columns on "behavior" and the "readers' letters" section publishing feminist ideas on the subject.

Keywords: Sexuality; women's press; Jornal das Moças; Capricho magazine; Cláudia magazine.

\section{Presse féminine et sexualité : 1946-1973}

\section{Résumé}

Cet article fait partie d'une recherche dont l'objet d'étude est les représentations sur le genre féminin et la sexualité des femmes construites par l'Église, la médecine et la presse féminine au Brésil entre 1946 et 1973. Ce découpage chronologique a pour objectif de tester l'hypothèse de l'existence dans le pays d'une disjonction entre libéralisation des mœurs et augmentation de l'autoritarisme politique. La période étudiée comprend ainsi deux conjonctures bien différenciées : celle qui s'est étendue de 1946 à 1964, marquée par une résistance culturelle associée à des transformations des valeurs traditionnelles en ce qui concerne les mœurs, et la période allant de 1964 à 1973, marquée de son côté par un autoritarisme politique croissant et une libéralisation des mœurs tout aussi importante. Nous mènerons ici une recherche empirique dans des revues féminines représentatives des différentes tendances de l'approche de la thématique de la sexualité dans chacune des conjonctures étudiées. De périodicités diverses, les revues de la conjoncture allant de l'après-guerre au début des années 1960 (Jornal das Moças et Capricho) étaient caractérisées par un traitement de cette thématique essentiellement indirect, à travers des publicités pour des médicaments liés aux dysfonctionnements de l'appareil reproductif féminin ou pour des serviettes hygiéniques. À partir du début des années 1960, nous avons analysé la revue Claudia, qui a été en mesure d'aborder la question de la sexualité de manière plus directe, aussi bien dans des articles réguliers sur le « comportement " qu'à travers le courrier des lecteurs, qui ont permis la diffusion des idées féministes sur le thème.

Mots-clés : sexualité ; presse féminine ; Jornal das Moças ; revue Capricho ; revue Cláudia.

\section{女性报刊和性问题: 1946-1973}

本文研究 1946 年至 1973 年之间巴西的教会, 医学, 和女性刊物对女性性别, 性问题的表述和话语构建。我们 选择这个时间段进行研究是因为在此期间, 巴西经历了在政治威权主义日益增强的情况下, 风俗习惯的日益自 由化, 并且因此产生了某种思想上的扭曲与脱节。因此, 在此期间, 出现了两种不同的社会背景: 从 1946 到 1964 年，文化抵抗运动之下的传统价值与风俗习惯的不断改变，此种改变从 1964 延伸到 1973 年，在此期 间, 政治威权主义不断增长, 但是风俗习惯却越来越自由化。本论文中, 我们根据经验分析这两个时段, 两种 背景下, 代表不同的思想倾向的女性杂志, 它们对性议题所持的各种观点。在第一阶段, 从二战后到 60 年代 初, 这些杂志 (青年女性 和任性) 只能间接触及有关性的议题, 而且是通过介绍治疗生殖器官障碍的药品广告 和女性卫生棉的产品宣传。从 60 年代开始, 我们分析了克劳迪娅 杂志, 该杂志在 “行为” 和 “读者来信” 的 常规栏目中探讨了性问题，同时传播了相关的女权主义思想。

关键词: 性议题; 女性出版物; 青年女性 (Jornal das Moças); 任性杂志 (Capricho); 克劳迪娅 (Cláudia)。 


\section{O corpo da mulher no Jornal das Moças e em Capricho}

Este trabalho compõem um conjunto de projetos de pesquisa (PINHEIRO, 2017), ${ }^{\text {a }}$ que teve como "objeto" de estudo as representações sobre o gênero feminino e a sexualidade das mulheres construídas pela Igreja, a Medicina e a Imprensa Feminina no Brasil entre 1946 e 1973. Este recorte cronológico inseriu-se na perspectiva de testarmos a hipótese de ter havido no país uma disjunção entre liberalização dos costumes e aumento do autoritarismo político. Assim, o período estudado compreenderia duas conjunturas diferenciadas: a que se estendeu de 1946 a 1964, e foi marcada pela resistência cultural combinada com mudanças de valores tradicionais no que tange aos costumes e a que se estende de 1964 a 1973, na qual observamos o crescente autoritarismo político e uma liberalização de costumes também crescente.

Vale salientar que estabelecemos o ano de 1973 como marco cronológico em virtude do mesmo indicar o momento de auge do autoritarismo político com o governo Médici.

Nesse sentido, concebemos que o projeto de país do regime militar contemplasse, não apenas, aspectos macropolíticos e econômicos, mas incluísse uma reflexão sobre a família e, de forma mais ampla sobre os costumes. Tal reflexão pode ser concebida, também, como um projeto que, não chegava a ser concorrente, mas consoante ao católico. Julgamos que o mesmo não tenha sido plenamente bem-sucedido do ponto de vista do regime.

Corrobora esta nossa hipótese, a existência, por um lado, de todo um trabalho de "censura de costumes" realizado pelos militares na produção artística e cultural do período que, entretanto, não foi capaz de deter os avanços neste campo específico, representados pela figura emblemática de Leila Diniz e pelo movimento da Tropicália, como também, no campo jurídico, pela aprovação da lei do divórcio em 1977, ainda na vigência do regime.

Quanto à relação entre Igreja e Medicina que visamos investigar, concebemos que tenha havido, no Brasil do segundo pós-guerra uma coincidência entre as estratégias formuladas por ambas as instituições tendo em vista disciplinar corpos e mentes femininos. Deste modo, de 1946 a 1968, supomos que as representações acerca do 
gênero feminino e da sexualidade das mulheres tratadas na pesquisa seriam eivadas de misoginia, tanto no âmbito do pensamento médico, quanto nas fontes de cunho teológicoclerical. De 1968 em diante, em função do início da Revolução Sexual e de avanços técnico-científicos da medicina no campo do controle da natalidade (popularização do uso da pílula anticoncepcional) o discurso desta instituição tenderia a se distanciar do discurso eclesiástico, avançando em relação a ele.

No presente trabalho utilizaremos como fontes primárias de pesquisa revistas femininas representativas de diferentes tendências de abordagem da temática da sexualidade, em cada uma das conjunturas em questão. Pesquisamos quatro revistas: Jornal das Moças (publicado entre maio de 1914 e dezembro de 1961) — período pesquisado: 1946-1961; Claudia (publicada entre abril de 1961-2000) — período pesquisado: 1961-1973; Querida (publicada entre abril de 1961 e abril de 1971) período pesquisado: 1961-1971; e Capricho (publicada entre junho de 1952-até o tempo presente) - período pesquisado: 1952-1973.

Quanto a estes periódicos, procedemos a um levantamento sistemático, levando em conta não perdermos a visão de conjunto em relação ao período estudado e podermos nos beneficiar da análise comparativa entre cada dupla de revistas pesquisadas para cada uma das conjunturas que analisamos. Nos valemos aqui do método de construção de intervalos de tempo aleatórios e recorrentes. Levantamos assim, três meses de cada ano, também escolhidos pelo mesmo critério.

Desta forma, com relação ao Jornal das Moças, procedemos a leitura e fichamento dos meses de maio, agosto e novembro de 1946, 1955, 1964 e 1973. Quanto a Capricho, lemos e fichamos os meses de junho, setembro e dezembro de 1952, 1956, 1964 e 1973.

Nestas fontes, a temática que nos interessa aparece nas propagandas de remédios: destinados a regular o fluxo menstrual feminino e/ou amenizar seus possíveis efeitos, e nas de absorventes higiênicos, uma novidade dos anos de 1940 que segue sendo tratada enquanto tal até meados dos 1960. Apesar disso, a linguagem rica em adjetivações se presta amplamente à análise.

A mulher da qual se fala em tal tipo de fonte e também, para quem as revistas se dirigem é, notadamente, aquela que ocupa o lugar, histórica e culturalmente construído como legítimo para as mulheres no Ocidente cristão, o lugar de esposa e mãe. Lugar sagrado que destitui quem o ocupa de corporalidade; daí o caráter secundário conferido ao corpo feminino em ambas as revistas. 
Tratado apenas no espaço destinado à propaganda, o mesmo ainda o é de forma marginal, já que uma das únicas de suas propriedades manifestas nas revistas é a da menstruação. Vejamos assim, de que forma este procedimento é utilizado por Jornal das Moças. No número de 2 de maio de 1946, a revista publica a seguinte propaganda de medicamento: "Seja bela e feliz [...]. Evite os sofrimentos do sexo tomando às refeições o regulador SIAN, que regulariza as funções femininas e dá saúde e beleza à mulher" (Jornal das Moças, 2 maio 1946).

Embora curto, o texto da propaganda reproduz uma visão negativa do sexo, percebido como fonte de sofrimentos para as mulheres. Além disso, veicula também, uma representação do corpo feminino que remonta à medicina do século XIX, em que o útero era tido como uma espécie de microcosmo da mulher, sede não apenas, de sua saúde ou doença, como ainda de sua felicidade ou infelicidade, beleza ou feiura. ${ }^{1}$ Tal representação ganha aspectos de tragicidade, noutra propaganda publicada neste mesmo número da revista:

\begin{abstract}
Neste mês vai sofrer outra vez? [...] Esta pergunta dirigimo-la a você prezada leitora. Você que como mulher está sujeita todos os meses, aos terríveis males resultantes do mal funcionamento de seus órgãos femininos. Terríveis males sim, por que além de transformarem a sua existência num verdadeiro martírio, esgotam com rapidez a sua saúde, a sua mocidade, a sua beleza. Ponha um ponto final neste capítulo de amarguras. Não sofra mais neste mês e em nenhum outro [...]. O Regulador Xavier [...] vai afastar definitivamente os seus males (Jornal das Moças, 2 maio 1946).
\end{abstract}

Fonte de vida quando saudável, o útero quando "funciona mal" transforma-se, à luz do texto da propaganda veiculada pela revista, em verdadeiro algoz da existência feminina. Capaz de transformá-la num martírio e converter-se mesmo em agente da morte para a mulher, esgotando-lhe a saúde, a mocidade e a beleza, esta representação do útero que Ihe confere tanto poder, torna necessário que lhe sejam dispensados cuidados especiais.

Associando, por um lado, saúde, mocidade e beleza e, por outro, doença, maturidade e feiura, o texto da propaganda, além de reproduzir uma representação de mulher carregada de misoginia por reduzi-la ao seu útero, ainda voltava uma especial carga de preconceitos contra as mulheres maduras.

Vejamos de que forma Capricho representava os corpos de ambas, mulheres jovens e maduras, ao longo de todo o período que pesquisamos. Tais representações

\footnotetext{
${ }^{1}$ Mary Del Priore recua as raízes desta visão acerca das mulheres aos séculos XVI e XVII. Quanto a esse assunto ver: Priore (1997) ${ }^{\mathrm{a}}$ Em relação à perspectiva consolidada na medicina do século XIX, ver: Rohden (2001). ${ }^{\text {a }}$
} 
também incorriam no fracionamento e redução do corpo feminino ao aparelho reprodutivo, já que somente os fenômenos a ele relacionados tinham algum espaço nas páginas desta revista. Em seu primeiro número, publicado em junho de 1952, deparamo-nos, com o fenômeno da menstruação tratado da seguinte maneira numa propaganda de absorventes:

Uma arquivista fica de pé o dia todo. Um trabalho interessante, mas é um andar de um lado para o outro o dia inteiro. E aqueles arquivos intermináveis dão a impressão de cobrir quilômetros de extensão, principalmente "naqueles dias"! Graças a MODESS, porém, atravesso esse período em inteiro conforto! [...] MODESS é o sonho de toda jovem, e é supermoderno (Capricho, ano I, n. 1, p. 19).

$\mathrm{Na}$ medida em que a proposta editorial da revista pretende identificá-la como "a revista da mulher moderna", é compreensível e coerente que localizemos nas páginas de seu primeiro número, uma propaganda de absorvente higiênico descartável que o classifique como a "solução moderna" para o problema da menstruação. Modernidade metaforizada, também, pela condição profissional da mulher que o utiliza, uma arquivista, presente no espaço público em função de seu trabalho. Cabe sublinhar tratar-se neste caso de uma modernidade reinventada pela empresa multinacional responsável pela fabricação do mencionado absorvente, já que também localizamos no Jornal das Moças, em número do ano de 1946, a seguinte propaganda do mesmo produto:

Se usa toalhas higiênicas comuns, veja o que dizem 1000 senhoras e senhoritas brasileiras consultadas sobre o assunto: Recente inquérito feito entre 1000 senhoras e senhoritas brasileiras, afirma que três entre quatro mulheres consideram o novo MODESS a mais segura proteção para os dias críticos. [...] Se ainda não usa o novo MODESS experimente este mês este novo conforto e proteção (Jornal das Moças, 2 maio 1946).

Diferindo do formato de propaganda publicada por Capricho, basicamente, em função da referência explícita que faz ao método, então hegemônico, de contensão do fluxo menstrual pelas mulheres, o das toalhas higiênicas não descartáveis, também não sinaliza de maneira nenhuma para a conquista feminina do espaço público no Brasil. Tal fato, certamente se explica pelas dimensões ainda muito tímidas desta conquista em meados dos anos de 1940.

A identificação do novo método, dos absorventes higiênicos descartáveis, com à ideia de modernidade, ocorre apenas no texto do cupom que a propaganda traz consigo para a solicitação de amostra grátis do produto, cupom através do qual o anunciante compromete-se, ainda, a enviar à futura consumidora, juntamente com o produto, um livrinho chamado "O que a Mulher Moderna deve Saber". 
A associação entre as ideias de modernidade e de uma "nova mulher" que pode adequar-se melhor a estes "novos tempos" se aderir ao consumo de produtos descartáveis, ainda não está plenamente construída neste formato de propaganda. Para que tal construção se concluísse, seria necessário que o mencionado processo de conquista feminina do espaço público avançasse.

Como tal processo avança no Brasil, precisamente, pela inserção da mulher no mercado de trabalho formal, é explicável que a "mulher moderna" imaginada por Capricho alguns anos depois, distingam-se das outras, justamente, por agregar, ao trabalho doméstico, o trabalho fora de casa. Este modelo de propaganda de absorvente adotado pela revista já em seu primeiro número, será recorrente para todo o período pesquisado, variando apenas quanto à profissão mencionada. ${ }^{2}$

Importa ainda, salientar que a grande maioria das profissões atribuídas à mulher nesse modelo de propaganda destina-se a mulheres jovens e se caracterizam pela condição de subalternidade que trazem consigo. Fica, assim, implícito que, ao longo das duas conjunturas estudadas, os cargos de chefia no mercado de trabalho formal brasileiro, estavam ocupados por homens, constituindo-se num dos muitos limites à conquista feminina do espaço público que se verifica no Brasil do segundo pós-guerra para cá. ${ }^{3} \mathrm{~A}$ chefia masculina é, inclusive, mencionada numa das propagandas da década de 1950 em que a subalternidade da mulher aparece também em sua dimensão psicológica. Assim, neste número da revista, a profissão de secretária é classificada como "uma posição invejável" mas, a personagem criada pela propaganda alega ter um "ótimo chefe", embora exigente, o que tornaria necessário estar "sempre alerta e bem disposta" (Capricho, ano I, n. 3).

Em relação ao tratamento dado no Jornal das Moças à questão do trabalho feminino, embora o tema não apareça nas propagandas de absorventes higiênicos publicadas nesta revista, tal como ocorre em Capricho, ela não se encontra totalmente ausente de suas páginas. No mesmo número de maio de 1946 em que localizamos, pela primeira vez nesta fonte, a aludida propaganda, encontramos também os seguintes

\footnotetext{
${ }^{2}$ No n. 2 do ano I, a profissão referenciada será a de balconista de loja, no n. 3, a de secretária, no n. 4, a de recepcionista de consultório médico. No n. 35 do ano IV, a propaganda de MODESS não alude a nenhuma profissão, mas a do concorrente faz referência a de secretária. No n. 147 do ano XIII, retorna o mesmo modelo de propaganda e a profissão mencionada é a de recepcionista de companhia de aviação. No n. 151 deste mesmo ano, a profissão a que se alude é a de decoradora.

${ }^{3}$ Para uma análise que enfatiza, por um lado, a natureza das tarefas e postos de trabalho habitualmente atribuídos às mulheres na indústria brasileira, voltando-se, por outro, para as representações que informam as diretrizes e práticas das chefias de diferentes níveis hierárquicos, relacionadas à diferenciação entre tarefas "masculinas" e tarefas "femininas", ver: Rodrigues (1992). ${ }^{2}$
} 
dizeres dispersos no corpo do Jornal das Moças: "A mulher que trabalha deu, simplesmente, outra orientação a seu espírito laborioso. Fez de seu tempo um sacrifício a mais e leva sua força criadora a horizontes mais amplos. Mas é sempre a mulher e dizer mulher é dizer senhora do lar" (Jornal das Moças, p. 51, 2 maio 1946).

A ideia de natureza feminina com que a revista opera é bastante nítida, caracterizando-se, fundamentalmente, pela domesticidade. Embora exista a manifesta intenção, por parte da mesma, de enaltecer o trabalho que a mulher realiza fora de casa, cabe salientar que o referencia apenas como "trabalho", sem qualquer complementação que o diferencie do trabalho doméstico naturalizado. Assim procedendo, o Jornal das Moças acaba por comprometer a aludida tentativa de enaltecimento do trabalho feminino externo ao lar.

Retomando à análise de Capricho e, mais precisamente, da forma como a revista, por um lado, interpreta a questão da modernidade e, por outro, busca incorporá-la, em suas dimensões de dinamicidade — da vida da "mulher moderna" que, por exercer múltiplas funções, passa a ter que lidar com uma outra noção de tempo - e de "descartabilidade" e funcionalidade dos produtos mais adequados a estes novos papéis e a este novo tempo femininos (como os absorventes higiênicos, por exemplo), ela se mostra bastante limitada quando se trata de abordar a sexualidade feminina e a educação sexual dos filhos.

Nenhuma das duas temáticas é propriamente contemplada pela revista e seguem aparecendo também, somente nos espaços destinados à propaganda, embora de forma ainda mais marginal que a questão da menstruação. Assim, a temática da educação sexual se manifestará apenas nas mesmas propagandas de absorventes higiênicos já mencionadas e, mesmo nelas, a abordagem do tema será bastante indireta.

A propaganda cujo texto reproduzimos integralmente, bem como todas as demais mencionadas, também vem acompanhada de um cupom para encomenda de um livreto intitulado "Ser quase mulher [...] e ser feliz", classificado como "um interessante livreto de 25 páginas que ajuda as mulheres a passarem os dias críticos com despreocupação e conforto" (Capricho, ano I, n. 1, p. 19).

Tal detalhe, aparentemente sem importância, segundo concebemos, indica com precisão, a imensa dificuldade, ainda recorrente naquela época, de se tratar com clareza, num veículo que não tinha nem caráter científico, nem religioso-doutrinário, do funcionamento do corpo feminino. No início da década de 1950, nem mesmo nos espaços voltados à propaganda de absorventes higiênicos em revistas femininas, era possível 
abordar a questão da menstruação. Se tal não era possível devido ao caráter de tabu que ainda revestia o assunto, ${ }^{4}$ falar mais propriamente em sexualidade e em educação sexual não era, em hipótese nenhuma cabível.

A propaganda de absorvente publicada no o 35 do ano IV de Capricho alude da seguinte maneira à questão da educação sexual:

\begin{abstract}
Sua filha pode ter receio de perguntar, mas, ela precisa conhecer "certos fatos" relacionados com a vida feminina. Sua filha lhe agradecerá mais tarde, se a senhora a preparar desde já para receber como normais, certas transformações que ocorrem na vida de toda a mulher. Explicações sobre o organismo feminino, apresentadas de forma simples e compreensível, são encontradas no livrinho [...]. Ela também ficará sabendo que MODESS é o método moderno de proteção íntima (Capricho, ano IV, n. 35, p. 31).
\end{abstract}

Em meados dos anos de 1950, no que se refere à educação sexual, a revista limita-se, apenas, a publicar propaganda de empresa multinacional, portadora da modernidade norte-americana, em que se afirma a necessidade de que as meninas tenham acesso, pelo menos às explicações sobre o funcionamento de seus corpos. No âmbito desta propaganda, a mulher-mãe, tal como definida pelo modelo nuclear-burguês de família, é identificada como agente prioritário neste processo educacional.

Segundo Gizlene Neder (1994), ${ }^{a}$ a atribuição deste novo lugar à mulher no interior da família que a pressupõe como alicerce da moral familiar e social, relaciona-se ao processo de construção da ordem burguesa no Brasil. Nesta perspectiva, o projeto republicano dos militares que se inspirava no positivismo de Augusto Comte e foi vitorioso quando da proclamação da República no país, teria "deitado raízes no imaginário social" tendo, inclusive, adequado aspectos do modelo católico de educação feminina. Tal projeto ensejava a um só tempo: modificações de caráter conservador no plano econômico (configurando o que se convencionou chamar de "modernização conservadora" do país), um padrão de controle político e social excludente, e a mencionada reflexão sobre a organização das famílias que evocava o padrão burguês, tendo em vista normatizar, não apenas, as famílias das classes dominantes, como também as dos setores populares.

Neste "novo" modelo de família, as mulheres deveriam ser socializadas para desempenharem o papel de mães, convertidas nesta perspectiva, em educadoras dos filhos e suportes dos maridos, no sentido de capacitá-los ao enfrentamento das batalhas

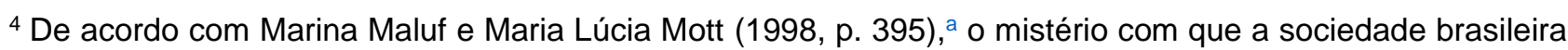
dos anos 50 cercava a menstruação pode ser medido por um episódio vivido na infância por $d$. Risoleta: "Disse para minha irmã: 'titia está com a doença da Dona Zenaide', minha mãe escutou. Aí deu uma surra de couro que até hoje quando me lembro dói. Sabe a doença o que é? É a menstruação. A patroa é que tinha essa doença $[\ldots]$ a gente via ela lavando aquela roupinha meio escondido, sabe criança como é? A gente já estava grandinha, mas nunca ninguém explicou [...]”.
} 
inerentes ao mundo do trabalho externo à casa. A "boa esposa" e "boa mãe" deveria, portanto, além de ser "prendada", demonstrando destreza no manejo e/ou gerenciamento das tarefas domésticas, ter acesso à educação formal para bem desempenhar sua tarefa como educadora.

Delineia-se, assim, o perfil da mulher-suporte, talhado pelos positivistas brasileiros do início do século como modelo para o "novo" Brasil (NEDER, 1994, b p. 30-32)..$^{5}$ É tal modelo de mulher que seguimos identificando na imprensa feminina do país em meados dos anos de 1950, acrescido apenas de uma nova atribuição, a de conferir aos seus filhos, além da educação formal subsidiária à da escola, um mínimo de educação sexual.

Retomando a análise da propaganda, cabe salientar que a multinacional responsável pela veiculação da mesma se destitui de qualquer função no processo educativo que recomenda, a não ser a de sublinhar a sua necessidade e indicar uma leitura que complemente as eventuais lacunas da mãe para realizar o papel de educadora que lhe atribui. Com relação a esta discussão, a revista, ao menos no decorrer dos anos de 1950, opta por omitir-se, passando a se pronunciar a respeito apenas, na década seguinte.

Assim, no mês de maio de 1964, localizamos numa das seções de cartas de Capricho, chamada "O coração pergunta, Magda Mason responde", a seguinte solicitação de uma das leitoras: "Mamãe não me deixa sair de casa e já falei a respeito com meu professor. Ele respondeu-me que eu devia ter uma conversa séria com mamãe. Nada sei sobre a vida e o casamento e minhas coleguinhas chamam-me de ingênua. Quero a resposta pela revista [...]"

A solicitação da leitora é respondida da seguinte maneira por Capricho, representada pela jornalista e conselheira da coluna Magda Mason:

\begin{abstract}
Estou de acordo com seu professor: você precisa conversar com sua mãe e mostrar-Ihe que uma vida equilibrada comporta obrigações e divertimentos alternados. Ficar presa em casa, só com estudos e trabalhos, enquanto as outras passeiam, não me parece medida eficaz de proteção à sua virtude. Pelo contrário: criará um clima de revolta e ódio. Quanto às "coisas" que você deseja saber, evidentemente, não será possível explica-las nesta coluna. Poderia citar-lhe alguns livros, mas receio que você seja muito pouco amadurecida para lê-los. Por que não pede à sua mamãe que esclareça suas dúvidas? (Capricho, ano XIII, n. 147, p. 33).
\end{abstract}

Duas outras instituições que poderiam exercer a função de educar para o exercício da sexualidade além da família, aparecem na correspondência trocada por Capricho e

\footnotetext{
${ }^{5}$ Para uma análise dos efeitos político-ideológicos que a visão positivista da educação feminina produz na formação histórico-social brasileira, a partir do estudo sistemático das obras literárias de Sophia Lyra, ver: Buthod (1993). ${ }^{2}$
} 
sua angustiada leitora: a escola, representada pela figura do professor citado na carta, e a própria revista, metaforizada na figura da articulista Magda Mason. Entretanto, ambas as instituições, através de seus representantes, reforçam a ideia tradicional de que a educação sexual é prerrogativa da família e, no interior da mesma, pelo menos em se tratando da formação das meninas, é função materna. A revista, portanto, literalmente, se recusa a prestar a informação que Ihe é solicitada.

Aqui, a demanda da leitora refere-se apenas às informações básicas acerca do funcionamento dos corpos e da sexualidade em geral, informações que declara não ter e, nem mesmo esta demanda pelo mínimo de conhecimento, a escola e a revista se sentem capazes de realizar. Também cabe sublinhar o fato das questões relativas à sexualidade não serem formuladas, nem no discurso da leitora, nem no da revista, sendo ainda tratadas como aquelas que se referem, genericamente, à vida e ao casamento e dizem respeito à virtude das mulheres.

O excessivo conservadorismo expresso na opção da revista pelo silêncio, em detrimento da informação, mesmo daquela de caráter normatizador, quando se trata de educar para a sexualidade, talvez não se explique apenas pelo contexto histórico anterior ao início da Revolução Sexual, talvez, a isso também se some uma linha editorial, realmente mais conservadora, ou mesmo receosa de ferir preceitos hegemônicos no acontecer social.

Esse conservadorismo é reforçado pelo tratamento, igualmente conservador e periférico, que a revista confere à temática da contracepção. Presente em suas páginas apenas a partir da seguinte propaganda que passa a veicular em meados dos anos de 1960:

Gravidez só quando você quiser [...] O Indicador, único aparelho de precisão importado da Suíça, calcula automaticamente os dias férteis de cada mês, por mais irregular que seja a mulher. É um aparelho científico aprovado pela Igreja. Milhares já em uso no Brasil garantem a confiança votada a este instrumento de precisão. Atenção, não confunda o Indicador com imitações duvidosas! Peça hoje mesmo folheto ilustrativo desta maravilhosa descoberta e veja como é fácil resolver seu problema conjugal! (Capricho, ano XIII, n. 147, p. 103).

Anunciando como novidade um método contraceptivo muito semelhante ao método de Ogino, que diferia dele apenas por buscar uma maior eficácia no cálculo dos dias férteis da mulher, a propaganda veiculada por Capricho aludia ainda de forma explícita à aprovação do mencionado método, tanto pela Igreja, quanto pela ciência, referindo-se também, ao fato de que o mesmo viria a resolver problemas conjugais relacionados à dificuldades de contracepção. O que tudo isso significa? 
O fato da contracepção não ser diretamente discutida pela revista, mas tratada por um anunciante que tem em vista a comercialização de determinado produto, não significa que não possamos tomar o discurso construído como discurso da revista em relação à temática em questão.

Neste discurso, verificamos uma intrínseca associação de pontos de vista com a Igreja Católica, não apenas porque o produto anunciado opera de forma muito semelhante ao único método que esta instituição permite aos seus fiéis, como também porque no corpo da propaganda se alude somente à sexualidade conjugal. Reproduziase, assim, a ideia de que as sexualidades pré-conjugal e extraconjugal não existissem; ideia condizente com a perspectiva católico-romana extremamente conservadora.

\section{Maternidade, conjugalidade e trabalho feminino na revista Claudia}

Com relação a Claudia procedemos a leitura e fichamento dos meses de maio, agosto e novembro de 1964 e de 1973. Já a Querida lemos e fichamos os meses de maio, agosto e novembro de 1964 e de 1968.

A revista Claudia, nos números relativos à década de 1960, refletia um momento de crise e transição de costumes no qual pretendia interferir, realizando um trabalho pedagógico com suas leitoras no sentido de identificar, para elas a opressão de que eram vítimas na sociedade e que se manifestava em seus próprios lares (relação conjugal e com os filhos). A revista procurava explicar-lhes a origem desta sujeição e indicar os possíveis caminhos de superação da mesma. As saídas sugeridas sublinhavam a necessidade de reforço da autoestima através de um processo de construção da identidade que tivesse como principal referência a escolha profissional e não a afetivoconjugal.

Este projeto de divulgação das ideias feministas encontrava-se claramente presente nos artigos assinados por Carmem da Silva, que também assinava a seção de comportamento e a correspondência que a revista mantinha com as leitoras. Tal seção transformava-se assim, a um só tempo, num importante instrumento de realização do projeto político de Claudia e de mensuração, tanto da extensão quanto das possibilidades de execução deste projeto; ${ }^{6}$ como é possível perceber a partir do seguinte diálogo travado

\footnotetext{
${ }^{6}$ Uma coletânea dos artigos publicados por Carmem da Silva nos 22 anos em que escreveu para Claudia foi republicada pela editora Rosa dos Tempos em 1994. Ver: Civita (1994). ${ }^{a}$ Em relação às posições defendidas pela autora em seus artigos ver: Ribeiro (1995). ${ }^{a}$ A apreciação da autora sobre o conteúdo político-ideológico da atuação de Carmem da Silva em Claudia é muito semelhante à nossa.
} 
entre Carmem da Silva e Maria de Lourdes Moraes, uma leitora que escreve à revista de Santos, São Paulo, em maio de 1964:

Lendo seu artigo ("você vive no tempo presente?") achei a argumentação brilhante, mas nada prática... Na prática, vivemos ainda no regime do casamentoemprego para a mulher. Em que pesem todas as conquistas da emancipação feminina, as jovens querem casar o mais breve possível. E poucos pais tem autoridade suficiente para dar às suas filhas uma profissão, antes de entregá-las à um homem [...]. A jovem altamente intelectualizada, que espera e escolhe um marido à sua altura, estará fatalmente fadada à solteirice. $\mathrm{E}$ há muita gente boa que ainda ache que profissão para mulher é derivativo de casamento. Estupidez humana, mas é com essa estupidez que temos que nos haver porque não podemos reformar o mundo (Claudia, ano IV, n. 32).

A esse retrato resignado do mencionado contexto de crise e transição de costumes, Carmem da Silva responde da seguinte forma:

Estou totalmente de acordo com seu diagnóstico da sujeição feminina [...]. Discordo, contudo, de sua afirmação de que não se pode reformar o mundo; acho que se pode e se deve fazê-lo. A Sra. está amistosamente "intimada" a depor seu ceticismo [...] e colaborar na obra didática que Claudia trata de realizar entre as mulheres (Claudia, ano IV, n. 32).

A resposta da articulista que fala por Claudia, não deixa dúvidas quanto ao conteúdo político-ideológico do projeto da revista em relação a suas leitoras, trata-se de educá-las para o exercício da autonomia e da liberdade. Deste modo, a crença no caráter revolucionário da educação, percebida como instrumento de transformação social, tornase central a este projeto.

Cabe, atentar para o fato de que, a afirmação de compromisso com "a mudança do mundo" através da educação, é formulada por Carmem da Silva e publicada por Claudia posteriormente ao golpe de 1964, o que talvez sinalize para um comprometimento mais amplo da revista em relação à questão das transformações sociais e políticas necessárias ao país. ${ }^{7}$

Com relação à questão da sexualidade em suas múltiplas dimensões, verificamos uma série de mudanças na abordagem da mesma por Claudia, tendo-se como referência o que foi encontrado nas revistas Capricho e Jornal das Moças. Assim, tal questão não mais se encontra restrita ao espaço destinado a propaganda de absorventes higiênicos e medicamentos para as disfunções do aparelho reprodutivo feminino, passando a ser contemplada noutros espaços da revista como, por exemplo, a mesma seção de cartas.

Assim, numa carta intitulada "Do passado...", a leitora, que assume o nome de "Flor Perdida", uma moça de 22 anos, habitante da cidade de Piraju, no interior paulista,

\footnotetext{
7 A publicação de uma matéria assinada por Vladmir Herzog, jornalista que, posteriormente, seria assassinado pela ditadura militar, neste mesmo número de Claudia, constitui-se em indício que reforça nossa hipótese da revista posicionar-se mais à esquerda, também quanto às questões macropolíticas.
} 
narra uma história de defloramento seguida de abandono, difamação e tentativa de suicídio, à que Carmem da Silva responde da seguinte maneira:

\begin{abstract}
Você não está "desonrada" como afirma, mas sim humilhada e dolorida. Sei que as pequenas cidades são sumamente cruéis com quem não se curva $100 \%$ às suas normas. [...] Não se feche em si mesma, estude, trabalhe, leia e, sobretudo procure a pessoa com quem você possa desabafar. [...] Responda com altivez ao desprezo [...] Apoiada por uma boa amizade, você reagirá com o tempo, e estará livre para uma nova escolha, mais de acordo com seus sentimentos e sua razão (Claudia, ano IV, n. 32).
\end{abstract}

Coerente em relação às ideias de liberdade e autonomia femininas aplicadas, inclusive ao exercício da sexualidade, Carmem da Silva, além de desconstruir a tradicional noção de que a honra das mulheres estaria vinculada a sua conduta sexual, ${ }^{8}$ sugeria à sua sofrida leitora que o trabalho, a atividade intelectual, a busca de uma sincera amizade e, sobretudo, a altivez, pudessem constituir meios eficazes de combater a dor do abandono e da humilhação. Assim procedendo, realizava dentro do que lhe era possível, um trabalho de divulgação do ideário feminista e rompia, em alguma medida, com a visão acerca de gênero e sexualidade que identificamos nas revistas pesquisadas para as conjunturas anteriores.

Voltando a questão da sexualidade das mulheres jovens que aparece em Claudia intrinsecamente relacionada à temática da educação sexual, localizamos outras atitudes de Carmem da Silva dignas de nota em muitos sentidos. Assim, diante de uma leitora que se queixa da excessiva rigidez de sua educação no que se refere a informações sobre sexo, a jornalista lamenta que a mesma não tenha ninguém ("amigo" ou "parente") para conversar sobre este assunto, e lhe recomenda um psicólogo para ajudá-la a "perder o medo de casar" e tirar-Ihe as dúvidas sobre sexo. Além disso, Carmem da Silva também Ihe indica a leitura do livro Sexo sem culpa, de Alfred Ellis, editado pela Ibrasa.

Em relação às posturas adotadas por Capricho e pelo Jornal das Moças diante de situações semelhantes, percebemos que Claudia avança em alguns aspectos. Entre estes

\footnotetext{
${ }^{8}$ Para uma análise que explica as concepções hegemônicas acerca da mulher no pensamento jurídicopenal do Ocidente cristão a partir da hegemonia do pensamento religioso e do direito canônico, ver: Cerqueira Filho e Neder (2001). ${ }^{a}$ Nesse artigo, os autores se referem, por exemplo, à obra de Francisco Viveiros de Castro, de 1897, intitulada "Os Delitos contra a Honra da Mulher", como uma das obras do direito penal brasileiro, em que a mulher que é violentada é vista não como vítima, mas como ré. Segundo os autores "ela é considerada responsável pelo estupro, pois se este se deu fora do lar, significa que a mulher expôs-se ao mal (na rua, lugar fora do espaço doméstico/familiar), possibilitando a exteriorização do mal que só ela possui - a sedução" (CERQUEIRA FILHO; NEDER, 2001, p. 118). ${ }^{\text {b }}$ Os autores observam ainda que, apesar do livro utilizar-se de uma linguagem jurídica moderna para analisar os delitos contra as mulheres, especialmente aqueles dirigidos contra seus corpos (estupro e sedução), o mesmo mostra-se envolto num emaranhado ideológico em que os preconceitos do conservadorismo clerical, que veiculam uma imagem depreciativa e misógina da mulher, manifestam-se vivamente (CERQUEIRA FILHO; NEDER, 2001, p. 118). ${ }^{c}$ Ver ainda: Debert e Ardailon (1987); ${ }^{\text {a }}$ Besse (1989). ${ }^{a}$
} 
se encontra a indicação de uma leitura como forma de intervenção no processo de educação sexual do qual a missivista se queixa, e de uma leitura que aborda questões subjetivas inerentes à sexualidade, não se atendo apenas aos aspectos meramente fisiológicos da mesma.

É possível afirmar que, embora a intervenção da revista no mencionado processo educacional ainda se dê de forma indireta, já que as informações solicitadas não são passadas pela mesma à leitora, o livro indicado não parece tratar o sexo de forma isolada das emoções que o acompanham, o que já implica numa concepção mais ampla acerca da sexualidade. Impressão que se reforça pela indicação complementar de um psicólogo à mesma leitora. Se tivermos em mente que a articulista de Capricho sequer se permitia indicar leituras às suas angustiadas missivistas, teremos como dimensionar o avanço presente na postura de Carmem da Silva em relação a ela.

Tal postura revela-se, também, na resposta dada pela jornalista à carta de Nilza Aguiar, uma mineira de Belo Horizonte, que dirige à Claudia a seguinte solicitação:

Tenho quatro filhos, um de 19 anos, uma de 10, um de 7 e um de 4 . Sou muito feliz com eles. Sempre fui de opinião que as meninas, principalmente, devem ser esclarecidas sobre o problema biológico e sexual pelos próprios pais, [...] sem terem que fazer perguntas a colegas. Venho, pois, pedir-lhe que indique alguns livros que deverei dar a minha filha, expondo-Ihe com clareza e simplicidade a evolução da menina-moça (Claudia, ano IV, n. 35, p. 8, grifo nosso).

Resposta na qual, Carmem da Silva manifesta-se da seguinte maneira:

Permita-me, inicialmente dizer, que concordo plenamente com sua opinião. Pena que nem todos os pais se lembrem desta noção tão verdadeira: é melhor que os filhos fiquem conhecendo os porquês em casa do que fora. Por isso, dou com todo o prazer as informações que pede, embora já tenha feito, aqui mesmo, na edição de janeiro. Sugiro-lhe os seguintes livros: "A vida começa com um ovo", de Déa Heygate (muito recomendado); "A vida sexual feminina", Dr. Alfred Matter; "Responsabilidade sexual da mulher", de Maxime Davis; "O que as mulheres devem saber", de Edgar de Carvalho; "Sexo e amor", de Frank S. Cáprio. E, para ajudá-la (à senhora, bem entendido) a tratar do assunto com os seus filhos, recomendo "Problemas da adolescência" de Offélia Boisson Cardoso (Claudia, ano IV, n. 35, p. 8, grifo nosso).

Segundo concebemos, este novo papel que a revista desempenha, de intervenção na educação sexual das meninas, através da indicação de leituras específicas às suas mães, aponta para o surgimento, na sociedade brasileira, de novas possibilidades de aquisição de informações acerca da sexualidade humana. Informações que, uma vez adquiridas pelas mães, passam a poder ser retransmitidas às filhas. Neste caso, tais questões voltam a restringir-se ao âmbito da fisiologia, que segue sendo percebida pela mãe que recorre a revista como um problema (“o problema biológico e sexual”). 
Quanto ao mencionado processo de educação, vale salientar com base nesta fonte de pesquisa que, embora algumas mães, em meados dos anos de 1960, já julgassem necessário educar sexualmente suas filhas, é possível concluir que, além de não constituírem maioria, não sabiam, ainda, como fazê-lo. Cabia, à revista, através da figura de Carmem da Silva, preencher tal lacuna.

Contudo, as dúvidas das mulheres não se restringiam apenas à educação das filhas, estendendo-se, muitas vezes, à sua própria vida sexual, como demonstra a seguinte correspondência entre Carmem da Silva e uma paulista que se identifica como advogada e assume o cognome de "Doutora". A leitora queixa-se de que está casada há dois anos, tem uma filha de um ano e, desde que a menina nasceu, sente-se insatisfeita e insegura, pois seu marido "só é amoroso com ela" quando viajam em férias sem a filha, recebendo a seguinte resposta da revista:

\begin{abstract}
Você teve uma educação rígida [...], condicionada para se defender de qualquer intimidade antes do tempo. Seu marido também foi ensinado a ver na esposa, "a futura mãe de seus filhos", isto é, um retrato da própria mãe. O que aconteceu depois da lua de mel? Você ficou grávida e se tornou mãe, passou a ser "sagrada". Felizmente, seu marido não está completamente estragado por essa fantasia de mãe intocável, pois se saem de férias os dois sozinhos, [...] ele é capaz de reencontrar uma sensualidade satisfatória. Veja se, no dia-a-dia, você não está se portando como mãe devota, veja também se [...] ele não está trabalhando de forma desgastante. Enfim, depois de procurar as possíveis falhas no seu [...] comportamento, trate de dialogar com ele francamente. Afinal, se ele pode ser um excelente "marido de férias" é porque tem aspectos positivos no casamento e uma capacidade de reação que vale a pena estimular. Não o humilhe [...] Mas, procure incentivá-lo (Claudia, ano 12, n. 140, grifo nosso).
\end{abstract}

Do ponto de vista do ideário feminista, a carta mostra-se politicamente correta. Identifica a rigidez do processo educacional a que marido e mulher foram submetidos em suas famílias de origem, como fonte dos problemas sexuais que enfrentam. Tais problemas resumir-se-iam na sacralização da figura da própria mãe, pelo marido, e na projeção desta imagem sacralizada na esposa, quando a mesma se torna mãe. Processo classificado por Carmem da Silva como "fantasia de mãe intocável", que resultaria na dessexualização da relação do casal, excetuando-se os períodos de férias de ambos, com relação às funções de pai e mãe. $O$ que fazer quanto a este quadro sintomal construído pela jornalista?

A saída por ela indicada seria o diálogo franco e aberto entre o casal, como resultado de um processo de autoquestionamento iniciado pela mulher. A conselheira, entretanto, recomenda: "busque o diálogo, sem humilhá-lo". Assim, deixa implícito que a dificuldade sexual vivenciada por ambos, do ponto de vista da ideologia dominante, 
poderia incidir de forma negativa sobre a autoestima do homem, por colocar em xeque sua virilidade.

Além da sexualidade, outra questão também muito recorrente em Claudia no período que analisamos é a questão do trabalho feminino. ${ }^{9}$ Fundamental ao ideário feminista por ser percebida no âmbito do mesmo como um dos principais instrumentos de construção da autonomia das mulheres, a questão do trabalho feminino, aparece em diversos espaços da revista.

$\mathrm{Na}$ seção de cartas assinada por Carmem da Silva, tal questão surge, vez por outra, claramente articulada ao projeto político-editorial de difusão do feminismo abraçado por Claudia, como é possível verificar na seguinte carta enviada por Maria de Lourdes Michelon, de Erechim, Rio Grande do Sul. Importa atentar para o tom em que a carta é redigida pela missivista, tom que também é assumido por Claudia nos comentários que tece em relação à mesma:

A amizade de Claudia e Maria de Lourdes Michelon começou em 1962, quando Claudia era uma revista de alguns meses de existência. Com o passar dos anos, a amizade tímida foi se solidificando e, hoje, soubemos com grande alegria que, desde nosso primeiro contato, ocupamos um lugar de muita importância na vida da nossa querida leitora de Erechim, no Rio Grande do Sul. Eis a carta que recebemos de Maria de Lourdes (Claudia, ano 12, n. 140).

O tom de uma conversa entre duas amigas permanece na carta da leitora de Claudia que fala a respeito da história de sua relação com o marido, a qual se confunde com a própria história de sua vida adulta:

"Como resolvi meu problema: o trabalho salvou meu casamento": Hoje, após nosso encontro tão querido pensei em escrever-te, [...] tenho duas revelações importantes a fazer: a primeira diz respeito à nossa velha amizade, por isso te digo que, desde aquele nosso primeiro encontro em 1962, eu que era uma romântica mocinha de 18 anos, vibrei ao receber aquele exemplar "autografado" pelo mais charmoso dos namoradinhos e hoje, não menos "pão" dos maridos. Naquele primeiro número, confesso-te que os artigos não me diziam muito [...]. Noivamos, casamos, e os exemplares se sucederam aos meses e anos. O enxoval "bolei" quase todo com o auxílio de Claudia. As primeiras receitas de forno e fogão, idem. Do mesmo modo, Claudia me ajudou nas primeiras roupinhas e nas primeiras papinhas (Claudia, ano 12, n. 140, grifo nosso).

Até este momento da narrativa deparamo-nos com uma mulher contando o início de sua vida adulta que tem como ponto de partida o encontro com um homem e a descoberta do amor heterossexual, monogâmico e procriativo, por seu intermédio. Esta descoberta se faz, entretanto, acompanhar de um presente, um exemplar de Claudia. Até

\footnotetext{
${ }^{9}$ Quanto ao ingresso acentuado das mulheres no mercado de trabalho formal brasileiro a partir dos anos de 1970, um dos fatores que julgamos explicar a importância crescente deste tema nas páginas de Claudia, ver: Bruschini $\left(1989,{ }^{a} 1994 a\right)^{a}$ e Oliveira [1990?]. ${ }^{a}$ Quanto às principais tendências do debate teórico sobre o trabalho feminino, ver: Bruschini (1994b). ${ }^{a}$
} 
aqui, encontramo-nos apenas diante do mito do amor romântico e da representação de mulher que lhe é correlata, dependente e submissa ao homem até no que diz respeito às leituras que faz.

O elemento de contradição que desviaria esta história de seu curso tradicional encontra-se, entretanto, no conteúdo da própria revista com a qual o namorado/marido presenteia sua mulher. Conteúdo este que, de início, a incomodava bastante, como ela mesma revela à revista:

Mas algo me irritava na amiga Claudia [...], os artigos de Carmem da Silva que imaginava ser a mais incomplexada das mulheres [...] a dar ordens as mais estapafúrdias: a mulher não deve ser bibelô. Deve trabalhar fora e se emancipar! A esposa não deve ater-se a fraldas e bumbuns de bebês! [...] Eu discordava inteiramente de Carmem. Mensalmente eu lia e discordava. Mas lia (Claudia, ano 12, n. 140, grifo nosso).

Neste trecho da carta emerge a imagem estereotipada da feminista que sexualmente frustrada e afetivamente rejeitada (a expressão "incomplexada" poderia, em nossa perspectiva, ser, tranquilamente substituída por "mal-amada"), torna-se autoritária em função de seu ressentimento para com os homens (dá ordens estapafúrdias). ${ }^{10}$ Encarnada por Carmem da Silva, esta mulher-escritora (intelectual militante) que incomoda também pela inteligência manifesta na capacidade de expressão escrita, segue, entretanto, sendo lida e, a partir de um determinado momento da vida de sua leitora, seu discurso perde o caráter de agressão e passa a ser assimilado. É o projeto políticoeditorial da revista produzindo efeitos, como demonstram as passagens subsequentes da carta em questão.

Quando nossa filhinha fez dois anos, eu achei que deveria lecionar, mas em casa. Recomecei a estudar, pois largara o curso normal no segundo ano. Enquanto isso, Carmem, através de Claudia, me dizia coisas, e suas ideias já não me pareciam tão estranhas e agressivas. A transformação foi se dando aos poucos. Eu via perfeitamente que podia conciliar o papel de mãe, esposa e mulher atuante. Quando nosso segundo filho nasceu, o Marcelino, Carmem já entrara definitivamente no rol de minhas amizades (Claudia, ano 12, n. 140, p. 231, grifo nosso).

A transformação da leitora em relação à vivência de sua condição feminina, iniciase com a retomada dos estudos, provavelmente interrompidos por ocasião do casamento (isto fica implícito à narrativa), fazendo-se acompanhar da percepção de ser possível conciliar os papeis tradicionalmente imputados às mulheres nas sociedades patriarcais -

\footnotetext{
${ }^{10}$ Com relação à persistência de estereótipos que, do início do século XX aos anos de 1970, associaram o Feminismo à figura da mulher feia e mal-amada, ver: Ferreira (1995-1996). ${ }^{2}$ Nesse artigo, a autora sugere a relativa eficácia de tais estereótipos no sentido de neutralizar um movimento ou um conjunto de atitudes que apareciam como ameaçadores e radicais para amplos setores da sociedade.
} 
de esposas e mães - ao papel de "mulher atuante", até aqui ainda não identificado claramente como "mulher trabalhadora, profissionalizada e remunerada".

A esta altura, a principal articulista de Claudia, anteriormente identificada como feminista agressiva e autoritária, já é chamada por sua leitora pelo primeiro nome e classificada como amiga. A narrativa se segue com o relato das dificuldades econômicas vividas pelo casal, que acabariam por intensificar o processo de transformação da mulherleitora de, exclusivamente doméstica (esposa e mãe), em "mulher doméstica/atuante", profissional economicamente ativa e inserida no mercado de trabalho formal capitalista.

\begin{abstract}
Meu marido naquela época trabalhava em um banco, e eu já lecionava matemática e estudava para completar o segundo ciclo. [...] Quando o Milton deixou o banco para trabalhar de sociedade com um amigo, numa nova firma, as coisas, economicamente, começaram a ficar pretas. Num dia de muito "agradinho", insinuei alguma coisa como trabalhar fora. A primeira explosão foi quase violenta. Saíram palavras assim: - E os teus filhos? A casa? Mil problemas apareceram. Já na segunda vez foi um pouco menos e, na terceira, então, ficou tudo combinado. Eu tentaria arrumar um emprego de meio expediente, teríamos uma empregada fixa e eu faria a relação nominal das tarefas a serem executadas (Claudia, ano 12, n. 140, p. 231, grifo nosso).
\end{abstract}

Nesta etapa da narrativa, o aludido processo de transformação da leitora adquire novos contornos, com o surgimento de inúmeras contradições. Apesar de já lecionar matemática, sob o formato de aulas particulares ministradas em casa, tal atividade, embora remunerada, não é reconhecida nem por ela, nem pelo marido como um trabalho muito distinto do doméstico.

Assim, o agravamento da situação financeira de ambos torna necessária uma negociação repleta de conflitos em torno da possibilidade da mulher "trabalhar fora de casa". Nesta negociação, o marido ainda aparece como "cabeça do casal", uma espécie de chefe a quem se devia pedir permissão para ultrapassar, mesmo que minimamente, quaisquer dos limites intrínsecos à representação da feminilidade tradicionalmente doméstica.

No âmbito desta negociação, nossa leitora ainda se vê obrigada a transferir parte de suas atribuições dentro de casa a uma outra mulher, uma "empregada fixa" que deveria ser mantida sob seu rígido controle, necessidade manifesta em seu texto pela menção à "relação nominal das tarefas a serem executadas" pela empregada em questão. ${ }^{11}$ É possível imaginarmos que em meados da década de 1960 a hipótese de uma divisão mais igualitária do trabalho doméstico entre um casal de classe média, não pudesse, ainda, ser sequer cogitada por nenhum dos dois.

\footnotetext{
${ }^{11}$ Para uma análise acerca das relações entre patroas e empregadas domésticas na sociedade brasileira
} ver: Kofes (1993). ${ }^{a}$ 
Além da empregada, a leitora de Claudia tem também que "optar" por um "emprego de meio expediente", para não comprometer tanto, aos olhos do marido e aos seus próprios, o desempenho das funções de esposa e mãe. Prosseguindo em sua narrativa, ela avança na identificação das dificuldades que então se antepunham às mulheres com o seu pertencimento de classe que começavam a ousar transpor as fronteiras do espaço privado:

No fim do segundo mês fui chamada por uma firma de Engenharia e soube que fora selecionado entre quarenta moças, na maioria solteiras. Neste mesmo dia, recebi chamado da Secretaria de Saúde. Optei pelo funcionalismo em meio período. [...] As mudanças em nossa casa foram muitas, [...] mas quase todas para melhor. Meu marido parecia mais terrivelmente "ligado" em mim, as crianças já não ficavam tão manhosas. [...] Havia dias em que parecia que tudo ia estourar. Bastava uma noite de sono e o dia seguinte ficava bom de novo (Claudia, ano 12, n. 140, grifo nosso).

A narrativa se encaminha para o final e a missivista busca evidenciar os resultados positivos que o trabalho remunerado fora de casa teria produzido em sua vida doméstica, mais especificamente, em seu casamento, tornando o marido "mais ligado" a ela, e na relação com seus filhos, "menos manhosos" em função das ausências ocasionadas por seu trabalho. Os conflitos inerentes ao processo não são, entretanto, por ela camuflados. Assim, as mulheres solteiras seguem sendo consideradas concorrentes poderosas na disputa por um emprego, embora não invencíveis como sua própria experiência atesta.

De forma análoga, a maternidade segue sendo percebida como, a princípio, se não incompatível, de conciliação muito difícil com o trabalho fora do lar. Nesta perspectiva, uma nova gravidez, inicialmente recebida com apreensão, acaba por converter-se em fator de aumento de produtividade e revitalização das relações intrafamiliares (o nascimento do terceiro filho é recebido como se fosse o do primeiro):

Quando eu já trabalhava há quase um ano, fiquei grávida de novo. Momentaneamente "enlouqueci". Surgiram mil problemas e dúvidas que passaram após o primeiro mês. Funcionalmente foi o período de maior produtividade. Ao sétimo mês de gravidez, fui promovida a chefe de seção (estatística) e recebi portaria de louvor [...]. A gravidez deste terceiro filho foi a melhor possível, em se tratando de uma terceira cesárea. Patrícia nasceu linda e forte, e o Milton parecia pai pela primeira vez. Há dez meses atrás, meu marido foi transferido da capital para o interior. Eu pedi transferência e viemos para [...] Erechim. Trabalho em uma Delegacia de Saúde no período da manhã [...] e, as terças e quintas à tarde faço assistência social em uma comunidade religiosa (Claudia, ano 12, n. 140, grifo nosso).

A carta, por fim se conclui com um agradecimento a Carmem da Silva e, por conseguinte, à Claudia: "Não me arrependo de trabalhar fora e agradeço também aos conselhos de Carmem que muito me alertaram. No momento, além de tudo, faço o vestibular para Ciências Biológicas. Quem sabe?" (Claudia, ano 12, n. 140, grifo nosso). 
O processo de transformação/profissionalização da leitora da revista parece prosseguir com sucesso, revelando-se em plena adequação, não apenas com o projeto político-editorial de Claudia, como também com o momento de transição e crise de valores que a década de 1960 representou para as camadas médias urbanizadas no Brasil. Seu relato, ao invés de encarnar a plena consecução do ideário feminista da época, representa uma tentativa de conciliação entre a feminilidade tradicional (doméstica) e o modelo de feminilidade hegemonicamente defendido pelas feministas de então (em tudo oposto ao doméstico).

Retornando às temáticas de alguma forma relacionadas à questão da sexualidade, verificamos que a questão da geração da vida em seus mais diversos aspectos (biofisiológicos e psicoafetivos, principalmente), praticamente ausente das revistas anteriormente analisadas, também ganha relevância em Claudia. Podemos assim, localizar, por exemplo, num dos números de 1973, uma longa matéria sobre o problema da esterilidade ("Por que meu filho não vem?"), abordando, inclusive, a esterilidade masculina e seus aspectos psicológicos.

O tema da maternidade também é muito importante em Claudia, aparecendo em diversos espaços, tanto em seções de "caráter mais prático" (dicas sobre a confecção do enxoval do bebê, decoração do quarto e etc.), quanto em longos artigos sobre diferentes aspectos da relação com os filhos ("Quem manda na sua casa, você ou seu filho?") e, da relação mais específica com as filhas adolescentes ("A primeira visita ao ginecologista"). Nesta última matéria, entrecruzam-se diversas temáticas importantes para as reflexões que empreendemos. Claramente voltada para informar as mães no sentido de capacitálas enquanto educadoras das filhas, a matéria revela-se rica em detalhes sem, contudo, abandonar a precisão e a clareza das informações biofisiológicas fornecidas.

Entretanto, os aspectos subjetivos ligados à menstruação que, como afirma, marca a transição da menina para a condição de mulher, processo que não é simples, são deixados de lado. O título enfatiza a necessidade de que a moça seja informada pela mãe acerca do que está acontecendo com seu corpo e estabelece uma idade para a primeira consulta ginecológica: "Sua filha está ficando com jeitinho de mulher. Ela precisa saber o que está mudando; 10 anos: a idade da primeira visita ao ginecologista" (Claudia, ano 12, n. 142, grifo nosso).

O tom de normatização das condutas de mãe e filha (a filha precisa ser informada e sua mãe, ninguém mais além dela, precisa estar capacitada a fornecer-lhe as informações necessárias) permanece, sendo acrescido, no parágrafo inicial, de uma ideia que retorna 
noutros momentos da matéria e julgamos central à mesma, a da supostamente necessária medicalização do corpo feminino: ${ }^{12}$ "Em todas as fases de nossa vida contamos sempre com os cuidados de um médico, menos numa: a da puberdade, a adolescência, quando a jovenzinha mais precisa de uma orientação correta" (Claudia, ano 12, n. 142, grifo nosso).

A defesa desta ideia vem acompanhada, no corpo do texto, da concepção da puberdade como um período de dificuldades em que as jovens mulheres necessitariam de uma orientação especial, função que é prioritariamente atribuída aos médicosginecologistas. Nestes parágrafos iniciais, a matéria também explora um pouco os motivos que, na perspectiva de quem a redige, explicariam as dificuldades de algumas mães em substituir o pediatra das filhas pelos ginecologistas, como é possível constatar nas passagens que se seguem:

Cria-se um hiato: o lugar do pediatra, que deveria ser, automaticamente ocupado pelo ginecologista, fica vazio. Por quê? [...] Geralmente, porque as mães acham que só depois de ela se casar é que poderá passar por um exame clínico; outras, por vergonha e constrangimento. Afinal, todas essas razões surgem porque a própria mãe está desinformada a respeito. $\mathrm{E}$, neste caso, você deve ter segurança para saber explicar à sua filha o que está ocorrendo com ela (Claudia, ano 12, n. 142 , grifo nosso).

Esse conjunto de motivos poderia ser resumido, na perspectiva da revista, pela desinformação das mães, origem do "constrangimento" e da "vergonha" de algumas diante da ideia de submeter às filhas ainda virgens a uma consulta ginecológica.

Tal explicação, insuficiente e superficial por passar ao largo das questões subjetivas envolvidas com a manipulação do corpo feminino por um homem, mesmo que médico e por motivos de saúde, norteia a construção do restante da matéria no seguinte sentido: se o problema está na falta de informações das mães, trata-se apenas de informá-las da melhor maneira possível. Sendo assim, o passo posterior é o de descrever e conceituar o fenômeno da puberdade, o que é feito da seguinte forma:

Quando sua filha está ficando mocinha, isto é, deixou de se interessar pelas bonecas e brincadeiras para ficar esperando ansiosa uma festinha, filmes românticos e contos de amor, você deve manter com ela um diálogo franco e objetivo, evitando assim, que as coleguinhas (p. 95), tão pouco informadas quanto ela ajudem a criar fantasias e the transmitam ideias erradas [...]. O sinal mais evidente da puberdade é a primeira menstruação, que pode se dar entre os doze e os treze anos. Mas já uns dois anos antes surgem os primeiros sinais de maturidade física [...]. É nesta hora que ela precisa saber por que seu corpo está se transformando (Claudia, ano 12, n. 97, grifo nosso).

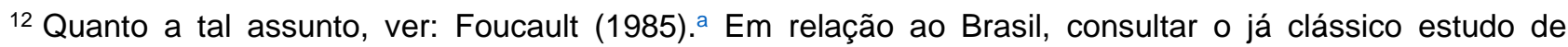
Jurandir Freire Costa (1983). ${ }^{\text {a }}$ Depois dessa obra, produziram-se muitas outras no país, também inspiradas em Foucault. Ver, por exemplo: Engel $\left(1989,{ }^{a} 1997\right)^{a}$ e Cunha (1989). ${ }^{a}$
} 
Assim, após uma definição tão subjetiva quanto duvidosa da puberdade como a fase da vida em que a menina começaria a interessar-se, obrigatória e naturalmente pelo sexo oposto e a acalentar o ideal do amor romântico, segue-se, contraditoriamente, uma definição que se atém apenas, aos aspectos fisiológicos que caracterizam o fenômeno. Deste momento em diante o tom da matéria passa a ser o de um manual de biologia humana.

Com o subtítulo de "Prepare sua filha para a primeira menstruação", a revista instrui as mães a estarem aptas para responder às seguintes questões formuladas pelas filhas: "O que é a menstruação? Por que a menina menstrua? O que é ovulação?”. Uma vez fornecidas as explicações tidas como necessárias acerca destes três processos chegam-se, por fim, a uma descrição dos órgãos genitais femininos que vem acompanhada das seguintes considerações sobre o hímen: "O hímen (uma pequena membrana que protege a entrada da vagina) tem um orifício central por onde escoa a menstruação e outras secreções da vagina. Ele é rompido quando a mulher casa e perde a virgindade" (Claudia, ano 12, n. 142, p. 97, grifo nosso).

Tal percepção da iniciação sexual como uma perda associada, exclusivamente, ao casamento, ${ }^{13}$ em nossa perspectiva, pode ser interpretada como uma contradição em relação ao projeto político-editorial de difusão do ideário feminista, abraçado por Claudia. Talvez, seja válida a hipótese de que tal projeto fosse, realmente, encampado, apenas pela intelectual militante que o assume de forma explícita, a articulista Carmem da Silva, não estando, portanto, tão presente nos demais espaços da revista.

A matéria se encaminha para o final, reforçando, novamente, a tese da medicalização necessária do corpo da mulher: "Mesmo que a menina entre na fase púbere sem nenhum problema, deve ser iniciado o hábito da consulta ao ginecologista. Acabou a infância e, com ela, a época do pediatra" (Claudia, ano 12, n. 142, p. 97).

Alçado à condição de uma espécie de "guru" ou guia espiritual, fonte de tranquilidade e segurança para as jovens mulheres, as mesmas, de acordo com Claudia, devem aprender com suas mães a depositar, não apenas alguma, mas toda a confiança neste profissional sem temer que ele "destrua sua virgindade", um bem sumamente valorizado pela matéria. Assim, de acordo com a revista:

Chegou a idade em que a menina começa a ter problemas de moça. E a melhor maneira de ensiná-la a viver tranqüila e segura é fazer com que sua filha deposite toda a confiança no médico-ginecologista. Existem médicos especializados em

${ }^{13}$ Quanto a esta representação da iniciação sexual feminina no Brasil contemporâneo, ver: Misse (1981)a e Parker (1991). ${ }^{a}$ 
ginecologia infantopuberal que podem examinar a mocinha sem por em risco a sua virgindade (Claudia, ano 12, n. 142, p. 97, grifo nosso).

A única contrapartida positiva desta extrema valorização do poder médico, ${ }^{14}$ que se opera no âmbito da matéria, encontra-se, segundo concebemos, na possibilidade de superação de alguns tabus relacionados à temática da menstruação, como se verifica na seguinte passagem de texto: "As dores ou cólicas muito fortes, antes e depois das menstruações, são motivos para se pedir conselhos ao médico. $O$ velho conceito de que 'mulher precisa passar por isso' não tem mais sentido. O ginecologista pode recomendar remédios contra essas dores" (Claudia, ano 12, n. 142, grifo nosso).

Mantendo-nos no terreno da temática da puberdade feminina, localizamos ainda, no mesmo número de Claudia, a propaganda de um aparelho para depilação, construída a partir de uma visão específica acerca desta etapa da vida das mulheres, que traz consigo uma determinada representação de feminilidade, bem como das próprias relações de gênero que Ihes são correlatas. Por tratar-se da única referência localizada em nossas fontes que atesta 0 uso deste fenômeno psicofisiológico para a comercialização de um produto diverso dos absorventes higiênicos, tão presentes nas páginas de o Jornal das Moças e de Capricho, vale a pena analisá-la:

Na época em que você se torna mulher, você precisa aprender outra coisa [...]: você precisa ficar sabendo que neste mundo difícil, ainda se pode encontrar um sistema civilizado e carinhoso para você cuidar das pernas e embaixo dos braços. Um sistema de depilar moderno e higiênico, não tendo nada que ver com aquele sofrimento ultrapassado, tão comum de acontecer durante a novela da depilação, em forma de cortes e cicatrizes, nas mulheres que se deixam levar por temas antigos como lâminas, ceras, cremes, líquidos e etc. (Claudia, ano 12, n. 142, p. 36, grifo nosso).

Nesses parágrafos iniciais, deparamo-nos com uma representação de puberdade bastante recorrente nas diversas fontes primárias de nossa pesquisa, que a identifica como uma época de transição na qual a menina assume, integralmente, sua condição de mulher, uma época difícil e de múltiplos aprendizados.

Ingressando no mundo das mulheres adultas, caracterizado pela propaganda como um "mundo difícil", a jovem mulher terá, entretanto, ao seu lado, um "sistema civilizado e carinhoso de depilação", "moderno e higiênico" que, no parágrafo subsequente é contraposto ao "sofrimento ultrapassado" dos "métodos antigos". O tema da modernidade, tão recorrente nas propagandas de absorventes higiênicos, retorna associado a um conjunto de representações positivas (civilização, carinho, higiene...).

\footnotetext{
${ }^{14}$ Para um estudo acerca do poder simbólico dos médicos e da predominância de médicos e bacharéis na cultura de elite no Brasil, com estudo de caso no estado do Maranhão, ver: Nunes (2000). ${ }^{\text {a }}$
} 
Nos parágrafos posteriores que encerram a propaganda, a depilação surge como uma metáfora da própria puberdade, dolorosa, mas necessária (marcada por "sangue, suor e lágrimas") e o produto anunciado aparece como uma forma de abolir a dor desta fase da vida das mulheres:

E o mais irônico é que nesta novela o final é quase sempre, bastante infeliz, marcado por sangue, suor e lágrimas. [...] A mulher que está vivendo no mundo de hoje pode trocar essa tragédia toda, pelo toque mais suave do século $\mathrm{XX}, 0$ toque de ladyshave da Philips. Um depilador feminino tão cuidadoso que só poderia ter sido inventado por quem conhece o assunto: os homens da Philips. [...] O único trabalho que os homens da Philips vão dar a você vai ser o mesmo que eles deram às americanas, francesas, holandesas, argentinas e outras mulheres do mundo inteiro. A duvidazinha que aparece na hora da escolha: ladyshave a pilha ou ladyshave elétrico? [...] Ambos fazem uma depilação bem feita e com segurança, acabando com seus dramas debaixo de bastante carinho (Claudia, ano 12, n. 142, p. 36, grifo nosso).

Nesses parágrafos conclusivos, os "homens da Philips" surgem como especialistas em mulheres e puberdade, aqueles que viabilizariam o fim do sofrimento feminino com suavidade e cuidado, enfim, "com muito carinho". Importa salientar que tal representação das relações de gênero, extremamente conservadora, tendo sido construída por uma empresa multinacional que se identifica como veículo da modernidade, é publicada numa revista feminina brasileira em 1973.

As contradições são inúmeras! No início dos anos de 1970, os ventos da Revolução Sexual, iniciada na Europa ocidental e nos Estados Unidos em fins da década de 1960, já sopravam em costas brasileiras. A revista que publicou tal propaganda, não era apenas feminina, mas trazia a si o papel de difundir entre as mulheres das classes médias urbanizadas no Brasil o ideário feminista. Além de tudo, é curioso notar como o mote da modernidade pode ser manipulado nos sentidos mais diversos, associando-se, inclusive, a representações muito conservadoras, como é o caso das relações entre homens e mulheres que a propaganda em questão propõe.

Nesse sentido, é possível comparar o uso da ideia de modernidade, ao que se opera nas propagandas de absorventes higiênicos muito recorrentes nas revistas femininas que circulavam no país entre o segundo pós-guerra e o final dos anos de 1950. Nestas, tal ideia aparecia articulada à imagem de mulheres dinâmicas e economicamente ativas, já presentes no mercado de trabalho formal capitalista.

Tal uso desta ideia conferia-lhe assim, uma feição mais progressista do ponto de vista dos costumes. Entretanto, não havia outros espaços em tais revistas para que representações análogas dos papeis sexuais fossem veiculadas. Também não era possível tocar, de nenhuma maneira em questões relativas à sexualidade. 
Nesta perspectiva, importa salientar que a abertura de outros espaços para a discussão de questões relativas a gênero e sexualidade na sociedade brasileira, e por conseguinte, nas revistas que nela passam a circular a partir dos anos de 1960, notadamente em Claudia, corresponda a uma modificação no padrão das propagandas de absorventes higiênicos, que passam a ater-se a descrição, meramente técnica, das características do produto.

O surgimento de propagandas de outros produtos também especificamente voltados para o público feminino como a que acabamos de analisar, em que se reproduzem representações mais tradicionais das relações de gênero, se inscreve igualmente neste mesmo contexto.

Ainda no campo das representações acerca da adolescência e das relações mãefilha adolescente, localizamos uma matéria sobre a questão da beleza ${ }^{15}$ nesta fase da vida que se presta amplamente à análise. Mantendo o tom de normatização das condutas de mãe e filha que verificamos na matéria sobre a primeira visita ao ginecologista, a reportagem em questão guarda algumas semelhanças com a anterior, mas acrescenta outros elementos à discussão da relação que pretende tematizar. Sob o título de "Você precisa ajudar sua filha adolescente a se descobrir e se valorizar", a matéria se inicia pela condução da mãe à condição de principal educadora da filha, como é possível constatar neste parágrafo: "É normal que uma adolescente comece a se preocupar com a beleza. $\mathrm{O}$ que você deve fazer é orientá-la corretamente: como e o que ela já pode usar. Assim você ganhará a confiança e a simpatia de sua filha, que começa e descobrir os primeiros traços de sua beleza" (Claudia, ano 12, n. 142, grifo nosso).

Anunciando que estabelecerá normas de conduta no que diz respeito a jovens mulheres e suas mães, o texto da reportagem segue associando beleza feminina à saúde. Sob o título de "A beleza começa com a saúde", coloca-se a seguinte questão às leitoras mães de adolescentes: "O que você acha de uma adolescente estar satisfeita com ela mesma, se achando bonita e charmosa? As mães devem reconhecer e admitir em suas filhas o desejo de serem mocinhas vaidosas, preocupadas com sua estética" (Claudia, ano 12 , n. 142, grifo nosso).

\footnotetext{
${ }^{15}$ Quanto a essa questão, importa lembrar que a estética corporal é inseparável de um trabalho sobre o corpo para o qual convergem saberes científicos e não científicos. Neste processo, o corpo se transforma em produção histórica, para onde convergem intervenções de todos os tipos desde os espartilhos e os coercitivos aparelhos de postura do século XIX até as obsessivas sessões de malhação das academias de ginástica da contemporaneidade. Para tal assunto, ver: SANT'ANNA (1995). ${ }^{a}$ Para uma abordagem sintética, com caráter de balanço acerca das principais questões de ordem teórico-metodológica e dos principais debates historiográficos envolvidos na construção de uma história do corpo, ver: Porter (1992). ${ }^{a}$
} 
Tangenciando a delicada questão da competição entre mãe e filha, que pode se instaurar a partir do momento em que a menina ingressa no mundo adulto, adquirindo características físicas e assumindo preocupações "de mulher", como a preocupação com a beleza, a matéria, no parágrafo subsequente, transforma a mãe no principal agente de controle sobre o corpo de sua filha, tendo em vista adequá-lo ao padrão hegemônico da estética feminina vigente na sociedade e na época em que ambas vivem:

Um especialista afirmou que a perfeição de um corpo feminino se consegue com a vigilância dos oito aos treze anos. A maioria das mães preocupa-se unicamente com a espera da primeira menstruação, esquecendo os fenômenos que antecipam esta data (Claudia, ano 12, n. 142, grifo nosso).

O texto avança fornecendo às mães algumas dicas no que se refere ao trato com as filhas adolescentes e, aos demais leitores, informações acerca do aludido padrão de estética feminina, vigente, pelo menos, entre as classes médias urbanizadas brasileiras no início dos anos de 1970.

É preciso estar atenta e ser cuidadosa quando falar com um adolescente. Um médico nos deu um exemplo de uma moça gorda, que teve durante toda a sua adolescência uma mãe que Ihe dizia: "é sempre meu bebê". Pensar que depois ela vai emagrecer é uma pena. Pense nisso: quando uma menina deixa de brincar com os irmãos, não quer mais fazer ginástica, come bolacha o dia inteiro, isto só poderá resultar numa jovem com problemas de beleza. Para ela conseguir um corpo delgado e equilibrado, compete à mãe nutri-la com inteligência e fazê-la movimentar-se [...] e, ao menor distúrbio, levá-la ao médico (Claudia, ano 12, n. 142, grifo nosso).

É possível identificar como característica deste novo padrão de estética feminina, tendo-se como referência a conjuntura anterior abarcada por nossa pesquisa, a desvalorização da obesidade nas mulheres, tendo como contrapartida a recomendação da atividade física para elas. Recomendação quase alçada à condição de prescrição médica. Verifica-se, assim, uma mudança quanto à percepção do significado da ginástica para as mulheres. Tida como negativa na primeira conjuntura, torna-se, não apenas positiva, mas também medicamente necessária. A extrema medicalização do corpo feminino, muito presente na matéria que versava sobre a primeira visita ao ginecologista, retorna na afirmação com a qual esta última se encerra: "ao menor distúrbio é necessário levar a menina ao médico".

Seguem, ainda, no corpo de tal matéria e sob a forma de um mesmo texto, dicas para a higiene pessoal, cuidado com as unhas, depilação e maquiagem com as respectivas indicações de produtos, cores, fragrâncias etc., tudo com as marcas correspondentes. Vale sublinhar que a indústria de cosméticos está intensamente 
presente entre os controles que se desenvolvem sob o corpo da menina, quase em pé de igualdade com a própria mãe e a figura do médico. ${ }^{16}$

A característica padrão de tudo o que se recomenda às adolescentes é a suavidade e a moderação, indícios que apontam para uma determinada representação de feminilidade, a do mito do eterno feminino ${ }^{17}$ que segue ainda, em alguma medida, sendo identificada como normal pela revista, apesar da popularização de algumas teses feministas através do trabalho de Carmem da Silva.

Ainda no que diz respeito à temática da maternidade, agora sob o viés da relação mãe-filho, não podemos nos esquecer de que no início dos anos de 1970, Claudia passa a incluir em seus números uma página de quadrinhos assinada por Ziraldo, que sob o título de "The Super-mãe", discutia, justamente, tal relação, sublinhando sua dimensão cômica.

Num dos números de 1973, evidencia-se o aspecto da crise geracional bem característica daquela época. A "supermãe", ao entregar o convite de formatura de um amigo de infância do filho, lembra-lhe de todo o sacrifício feito por ela, inicialmente com o marido, e depois sozinha, para que o mesmo concluísse os estudos e entrasse na universidade:

Tanta luta e você o que é que faz? Nada... um vestibularzinho de eu nem sei o que [...] E fica por aí, cheio de manias, conversando bobagem, cinema experimental, comunicação, língua [...] não sei das quantas [...],deitando tarde, acordando tarde [...] Sabe o que é isso aqui? O convite de formatura do Tomás: M-E-D-I-C-I-N-A! (Claudia, ano 12, n. 146).

Boa sátira da mãe dedicada que sofre em função da mencionada crise, não consegue compreender o filho e verbaliza a decepção de ver frustradas as suas expectativas em relação a ele. Afinal, mesmo naquela época tão diferente da sua no tocante à questão dos costumes e dos papéis sexuais, ainda havia rapazes que se formavam em medicina, uma profissão bastante tradicional e, portanto, capaz de transformá-los em futuros provedores de suas famílias de origem e/ou dos futuros núcleos familiares que poderiam constituir a partir desta profissionalização.

\footnotetext{
16 Para uma análise da forma pela qual a indústria da beleza e o culto à beleza feminina, no final dos anos de 1980, manipulam imagens que minam a resistência psicológica e material das mulheres, reduzindo as conquistas de 20 anos de lutas feministas, ver: Wolf (1992). a Para um estudo sobre a significação da aparência que tematiza a questão da moda, tendo em vista o impacto do feminismo no Brasil e os problemas de sua relação com o feminino e com os padrões de feminilidade destinados às mulheres, ver: Castro (1995-1996). ${ }^{\text {a }}$ Trabalhando de forma comparativa com revistas femininas de grande circulação e jornais feministas, a autora busca pensar as recusas do Feminismo diante do que identifica como feminilidade, entendendo tais recusas enquanto estratégias de luta contra as antigas molduras que enquadravam as mulheres em lugares demarcados e, supostamente, seguros.

17 Quanto a esse mito, ver: Misse (1981). ${ }^{\text {b }}$
} 
A título de tecermos considerações finais, julgamos ter trabalhado, com revistas femininas representativas de diferentes tendências de abordagem da temática da sexualidade, em cada uma das conjunturas estudadas.

Com periodicidades diversas, aquelas que cobriam a conjuntura que vai do pósguerra ao início dos anos 60 (Jornal das Moças e Capricho), se caracterizavam por tratar de tal temática apenas de forma indireta, através da propaganda de medicamentos para as disfunções do aparelho reprodutivo feminino e de absorventes higiênicos. Do início dos anos 60 em diante, a revista Claudia já teria condições de abordar a questão da sexualidade, tanto em colunas regulares sobre "comportamento", quanto nas "seções de cartas"; divulgando as ideias feministas quanto ao tema.

\section{Referências}

BESSE, Suzan K. Crimes passionais: a campanha contra os assassinatos de mulheres no Brasil: 1910-1940. Revista Brasileira de História: a Mulher e o Espaço Público, São Paulo, v. 9 , n. 18, p. 181-198, ago./set. 1989 . $^{\text {a }}$

BRUSCHINI, Cristina. Tendências da força de trabalho feminina brasileira nos anos 70 e 80: algumas comparações regionais. São Paulo: FCC, 1989. ${ }^{a}$

BRUSCHINI, Cristina. O trabalho da mulher brasileira nas décadas recentes. Revista Estudos Feministas, Rio de Janeiro, n. esp., jul./dez. 1994a. ${ }^{a}$

BRUSCHINI, Cristina. Trabalho feminino: trajetória de um tema, perspectivas para o futuro. Revista Estudos Feministas, Rio de Janeiro, v. 2, n. 3, p. 17-32, 1994b. ${ }^{a}$

BUTHOD, Maria Anita. Educação positivista e condição feminina no Brasil republicano. 1993. Dissertação (Mestrado) - Programa de Mestrado em Ciências Políticas e Sociais, Pontifícia Universidade Católica do Rio de Janeiro, Rio de Janeiro, 1993. Mimeo. ${ }^{a}$

CASTRO, Mayra Corrêa e. Feminismo prêt-à-porter: significação da aparência na imprensa feminina e feminista no Brasil. Cadernos AEL/Arquivo Edgar Leuenroth, Campinas, n. 3-4, p. 111-152, 1995-1996. ${ }^{a}$

CERQUEIRA FILHO, Gisálio; NEDER, Gizlene. Os filhos da lei. Revista Brasileira de Ciências Sociais, v. 16, n. 45 p. 113-125, fev. 2001. a, b, c

CIVITA, Laura Tavares (Org.). O melhor de Carmem da Silva. Rio de Janeiro: Rosa dos Tempos, 1994. ${ }^{a}$

COSTA, Jurandir Freire. Ordem médica e norma familiar. Rio de Janeiro: Graal, 1983. ${ }^{a}$

CUNHA, Maria Clementina Pereira. Loucura, gênero feminino: as mulheres do Juquery na São Paulo do início do século XX. Revista Brasileira de História: a Mulher e o Espaço Público, São Paulo, v. 9, n. 18, p. 121-144, ago./set. 1989. ${ }^{\text {a }}$ 
DEBERT, Guita Grin; ARDAILLON, Danielle. Quando a vítima é mulher. Brasília: Conselho Nacional dos Direitos da Mulher, $1987 .^{a}$

ENGEL, Magali. Meretrizes e doutores: saber médico e prostituição no Rio de Janeiro (1840-1890). São Paulo: Brasiliense, 1989. ${ }^{2}$

ENGEL, Magali. Psiquiatria e feminilidade. In: PRIORE, Mary Del (Org.). História das mulheres no Brasil. São Paulo: Contexto, 1997. p. 322-361. ${ }^{a}$

FERREIRA, Verônica Clemente. Entre emancipadas e quimeras: imagens do feminismo no Brasil. Cadernos AEL/Arquivo Edgar Leuenroth, Campinas, n. 3-4, p. 153-200, 19951996. ${ }^{\mathrm{a}}$

FOUCAULT, Michel. História da sexualidade: a vontade de saber. Rio de Janeiro: Graal, 1985. v. 1. ${ }^{a}$

KOFES, Sueli. Entre nós mulheres, elas as patroas e elas as empregadas. In: ARANTES, Antônio Augusto et al. (Org.). Colcha de retalhos: estudos sobre a família no Brasil. Campinas: Unicamp, 1993. p. 185-194. ${ }^{a}$

MALUF, Marina; MOTT, Maria Lúcia. Recônditos do mundo feminino. In: SEVCENKO, Nicolau (Org.). História da vida privada no Brasil. São Paulo: Companhia das Letras, 1998. p. 367-422. ${ }^{a}$

MISSE, Michel. O estigma do passivo sexual: um símbolo de estigma no discurso cotidiano. Rio de Janeiro: Achiamé/Socii, 1981. a, b

NEDER, Gizlene. Ajustando o foco das lentes: um novo olhar sobre a organização das famílias no Brasil. In: KALOUSTIAN, Manoug (Org.). Família brasileira: a base de tudo. São Paulo: Cortez/Unicef, 1994. p. 26-47. a, b

NUNES, Patrícia Maria Portela. Medicina, poder e produção intelectual. São Luís: UFMAPROIN-CS, 2000. ${ }^{\mathrm{a}}$

OLIVEIRA. Zuleica L. C. A mulher trabalhadora no estado do Rio de Janeiro (estatísticas em série). [S.I.: s.n.], [1990?]. Trabalho produzido para o projeto Sistema Integrado de Estatísticas por Sexo e Cor, sob a coordenação de Neuma Aguiar. ${ }^{a}$

PARKER, Richard G. Corpos, prazeres e paixões: a cultura sexual do Brasil contemporâneo. São Paulo: BestSeller, 1991.a

PINHEIRO, Anna Marina Barbará. Igreja Católica, medicina e imprensa feminina: representações sobre o corpo da mulher no Brasil republicano. Rio de Janeiro: Autografia, 2017..$^{a}$

PORTER, Roy. História do corpo. In: BURKE, Peter (Org.). A escrita da história: novas perspectivas. São Paulo: Unesp, 1992. p. 291-326. ${ }^{a}$

PRIORE, Mary Del (Org.). Magia e medicina na colônia: o corpo feminino. In: História das mulheres no Brasil. São Paulo: Contexto, 1997. p. 78-114. ${ }^{a}$ 
RIBEIRO, Mariska. Propostas revolucionárias. Revista Estudos Feministas, Rio de Janeiro, v. 3, n. 1, 1995. ${ }^{\text {a }}$

RODRIGUES, Araccy Martins. Lugar e imagem da mulher na indústria. In: COSTA, Albertina de Oliveira; BRUSCHINI, Cristina (Org.). Uma questão de gênero. Rio de Janeiro: Rosa dos Tempos, 1992. p. 266-288. ${ }^{a}$

ROHDEN, Fabíola. Uma ciência da diferença: sexo e gênero na medicina da mulher. Rio de Janeiro: Fiocruz, 2001. ${ }^{\text {a }}$

SANT'ANNA, Denise Bernuzzi de. Cuidados de si e embelezamento feminino: fragmentos para uma história do corpo no Brasil. In: . (Org.). Políticas do corpo: elementos para uma história das práticas corporais. São Paulo: Estação Liberdade, 1995. p. 121$140 .^{a}$

WOLF, Naomi. O mito da beleza: como as imagens de beleza são usadas contra as mulheres. Rio de Janeiro: Rocco, 1992. ${ }^{\text {a }}$

\section{Fontes primárias de pesquisa}

\section{Revistas}

Capricho: 1952 (junho, setembro e dezembro), 1956 (junho, setembro e dezembro), 1964 (junho, setembro e dezembro), 1973 (junho, setembro e dezembro).

Claudia: 1964 (maio, agosto e novembro), 1973 (maio, agosto e novembro).

Jornal das Moças: 1946 (maio, agosto e novembro), 1955 (maio, agosto e novembro), 1964 (maio, agosto e novembro), 1973 (maio, agosto e novembro).

Querida: 1964 (maio, agosto e novembro), 1968 (maio, agosto e novembro). 